\title{
CESAR MORO: ESCRITURA Y EXILIO
}

Elena Altuna

Universidad Nacional de Salta

$\mathrm{E}_{\mathrm{n}}$

un valioso ensayo sobre César Moro, Roberto Paoli señala dos aspectos que, a su entender, denotan en el poeta una voluntaria tendencia a la marginación. Ellos atienden, en primer lugar, a la elección del idioma francés como lengua en la que escribirá la mayor parte de su obra poética $y$, en segundo lugar, a la elección del surrealismo, concebida como praxis vital absolutamente ajena a las normas socioculturales de la Lima de los años veinte ${ }^{1}$. Efectivamente, este doble exilio -que fue también

1 -... la elección del francés significa primero el rechazo de la regla que quiere que cada cual escriba en la lengua que su destino nacional le ha deparado, aunque le guste menos que otra... En segundo lugar significa la opción por un exilio linguístico, por una marginación voluntaria, por una suerte de 'extranjeridad' en patria, en la ciudad de Lima, 'la horrible', con la cual estuvo divorciado hasta en el idioma, dificultando aún más ese comunicación que hasta en español hubicra sido trabajoso."

-Optó por un idioms extranjero y, como si no fuera suficiente, por un código lingüístico extranjero, el surrealismo que, además de ser extranjero, era rigurosamente contemporáneo $y$, por lo tanto, otra vez ajeno a un medio apegado a la tradición." Cfr. Paoli, Roberto, "La lengua escandalosa de César Moro" en Estudios sobre literatura peruana contemporánea, Firenze, Universitá degli Studi di Firenze, 1985, pp.131-132. Se podría agregar, además, la elección del nombre: César Moro, en sustitución de su verdadero y peruano nombre: Alfredo Quíspez Asín. 
físico, pues César Moro residió fuera de su pals durante años-parece ser una marca central de su escritura poética. No la registraremos en sus textos escritos en frances, sino en La tortuga ecuestre, poemario póstumo que recoge su producción en español ${ }^{2}$.

La figura del exilio actua en dos órdenes correlativos, que atienden tanto a los procedimientos poéticos, como a la temática nuclear del libro: el erotismo, en la medida en que la constitución del objeto poético-erótico conlleva la extrañeidad del sujeto con respecto a lo real y sus normas prefijadas. Es ese "impulso a no admitir lo real como definitivo e incambiable, a querer superarlo"3, en palabras de su amigo Westphalen, lo que llevará a Moró a buscarse como sujeto que re-crea define en el ámbito de un exilio poético en que se revela "la vida maravillosa".

"Visión de pianos apolillados cayendo en ruinas, texto que abre La tortuga ecuestre, propone una lectura surrealista del mundo, que opera como impugnadora del contexto cultural peruano (lectura que se justifica en la mención directa de la "república del Peru"); la ruptura de este ideologema (tradicionalismo, conservadorismo, apego al academicismo, hipocresía) se presenta a nivel sintáctico, semántico y de codigo literario vigente en lo cultural. La imagen de cuño surrealista del título -que conceta, en calve paródica con la persistencia del romanticismo tradicionalista a través de la resemantización de dos términos: visión y pianos)desacraliza, descomponiéndola, a la realidad limeña, emblematizada en el objeto piano, que constituye el campo

\footnotetext{
2 Moro, César, La cortuga ecuestre (1938-1939), en : Obra poétca, 1, Lima, Instituto Nacional de Cultura, 1980; prefacio de André Coyné, prólogo de Ricardo SilvaSantisteban. Citaremos por esta edición.

3 Westphalen, Emilio Adolfo, "Poetas en la Lima de los años treinta", prefacio a Otra imagen deleznable ..., México, Fondo de Cultura Económica, 1980,.p.119.
}

semántico de la decadencia y el acabamiento. El primer verso - El incesto representado por un señor de levita/ Recibe las felicitaciones del viento caliente del incesto" - es un sintagma circular, cerrado, que prolonga el mismo campo semántico, al que se añaden elementos poéticos de larga traición, la rosa y e pajaro, asociados a imágenes de ruptura: "rosa fatigada", "cadáver de pájaro", "pájaro de plomo"4. La acumulación de objetos diversos, algunos prestigiosos commo los citados, otros propios de la civilización (el reloj, la brújula, e mausoleo, las cuartillas de pape manuscritas en alemán) se proponen como metáforas de la cultura, puesta en peligro por la aparición de imágęnes que connnotan la naturaleza, las que irrumpenb a partir del adverbio: "Mientras". La aparente dispersión del texto encuentra, no obstante, su punto de cohesión en la repetición, en posición anafórica del verbo ser, cuya primera ocurrencia resume, globalizando, el haz semántico de muerte o acabamiento, ya que el sujeto de enunciado: "pájaro de plomo" está situado en un presente que se cierra inexorablemente:

Cuando acabes de estar muerto serás una brijula borracha

...

Serás un mausoleo a las víctimas de la peste o ... (p.51)

Los semas de inmovilidad e inutilidad clausuran un tiempo y un espacio; éstos se reabren a una segunda instancia, no necesariamente consecutiva, que opone a lo anterior la serie de la naturaleza. La irrupción de elementos como humo, paja algodón, etc. (el sintagma "vestigios de

4 Elementos como "rosa", "canto" o "pájaro", que emblematizan la poesía tradicional, serán retomados por ta vanguardia y resemantizados; tal el caso de Vicente Huidobro. 
alta arqueologia" evoca civilizaciones pretéritas de todos modos revalorizadas por los surrealistas) en progresión, dinamiza el tiempo detenido, a la vez que connota la presencia de otra realidad -la visión- que surge por la conversión de "mausoleo" en "volcán minúsculo". Lo Igneo constituye un elemento positivo, no solamente en la obra de $\mathrm{Moro}^{5}$, sino en general en todo el surrealismo, y su presencia transforma "pianos apolillados cayendo en ruinas"/ "pianos fuera de uso", objetos culturales caducos en nuevos objetos, en los que se puede "hacer crecer el trigo".

El poema inaugural de $\mathrm{La}$ tortuga ecuestre puede leerse, entonces, como la posibilidad de una práctica poética diferente, a partir de procedimientos como la creación de imágenes inusuales, ligadas de manera espacial más que semántica o sintácticamente; la casi ausencia de verbos, lo inacabado del poema, la ruptura de las fronteras netas entre poema y prosa, operan como disparadores de una "visión" pictórica o cinematográfica que atenta contra la "visión" representacional. La coexistencia de objetos disímiles, así como el avance de elementos pertenecientes a la naturaleza, constituyen una marca permanente en el texto. Así, el título $\mathrm{La}$ tortuga ecuestre pone ne relación dos ordenes: lo animal, acuático o terrestre y lo construido (en tanto connota estatua) y aéreo, lo que plantea una zona de indeterminación, de entrecruzamiento de elementos que alteran lo real. La tortuga forma parte de un extenso bestiario ${ }^{6}$, lo

\footnotetext{
5 Aspecto que fuera trabajado por Marths Canfield en su artículo "Cessar Moro ladro di fuoco" en Sinopsia 8. Anno III (Padova, 1987) pp.20-24, y retomado con mayor amplitud, desde una perspectiva psicoanslítica en Canfield, Martha, "Gnosis de la tiniebla: César Moro". En Configuración del arquetipo, Firenze Universitá degli Studi Di Firenze, 1988.

6 La "Lortuga" aparece mencionada en varias oportunidades a lo largo del texto: "la tortuga musical divina y
}

que singulariza la producción surrealista de Moro frente a la vanguardia hispanoamericana que, en la línea de cosmopolitismo, tematizó fundamentalmente un espacio ciudadano. En los textos que integran La tortuga ecuestre. asistimos a la construcción de una zona de pasaje, de contacto entre lo extenso y continuo -el reino de la naturaleza metaforizado en la "tortuga divina"- y lo discontinuo, el cuarto, el cuerpo, que desatan sus límites al operarse en ellos la transformación de la realidad. Esta permutabilidad de zonas y universos discursivos se presenta a la base de la revolución del lenguaje del surrealismo y tiende a la disolución de las oposiciones elaboradas por la cultura. En la escritura de César Moro las categorías ordenadoras vigentes en las prácticas sociales son impuganadas mediante un procedimiento preciso: la geminatio, o repetición textua de una parte de la frase que, a la vez que ancla el objeto poetizado en la iteratividad, desencadena la acumulación de elementos disímiles; ello produce undoble efecto de fijeza y dispersión, el uno en el orden de lo paradigmático, el otro en el orden de lo sintagmático. Así, en "El olor y la mirada", leemos:

El olor fino solitario de tus axilas

Un hacinamiento de coronas de paja y heno fresco cortado con

dedos y asfódelos y piel fresca y galopes lejanos como perlas

Tu olor de cabellera bajo el agua azul con peces negros y

estrellas de mar y estrellas de cielo bajo la nieve in-

calculable de tu mirada

Tu mirada de holutoria de ballena de pedernal de lluvia de

cretina" (p.51), "adorables tortugas como soles poblando el mar" (p.56), "el caparazón de primera magnitud" (p.67), "ls corteza rugosa de la tortuga ecuestre " (p.67). 
diarios de suicidas húmedos los ojos de tu mirada de pie

de madrépora ... (p.52)

texto en el que el polisíndeton funciona como elemento cohesivo de una sumatoria de significantes, que rodean a los objetos nominados. Este continuo movimiento de encierro fija el significante e instaura una suerte de escena mirada. El procedimiento se acentúa, a nivel sintáctico, por la escasez de verbos, y se articula, a nivel semántico, en el segmento final:

Y golpes centelleantes sobre las sienes y la ola que borra

las centellas para dejar sobre el tapiz la eterna cuestión

de tu mirada de objeto muerto tu mirada podrida de flor (ibid.).

La geminatio opera, en otros momentos, en el nivel fónico produciendo cadenạs de similaciones; así, por ejemplo, en "Un camino de tierra en medio de la tierra" : "...el área de tu frente asaltada por olas/ Asfaltada de lumbre... " (p.52) en donde la asociación surge por asimilación de la fricativa sorda /f/ a la Ifquida $/ 1 /$, enriquecida por la asimialción fónmica interna con el elemento de iunctura /olas/:/ ASALTADA por OLAS ASFALTADA/; asimilación que también se produce en /huELLAS LEVES y lava veRDE/.

Este procedimiento es metapoetizado en poemas como "A vista perdida" o "El fuego y la poesia", textos susceptibles de ser leídos como un arte poética. En ambos, la geminatio se relaciona estrechamente con el tema de la mirada, que Moro sintetizU en un pasaje de La chateau de Grisou (1943): "Tout le drame se passe dans l'oeil et loin du cerveau"7.

7 Citado por Sucre, Guillermo, "La poesía del cuerpo" en la máscara, la transparencia. Ensayos sobre poesía
Efectivamente,como veremos, la cuestión de la mirada es fundamental en la constitución del sujeto poético y adquiere variadas significaciones a lo largo de texto.

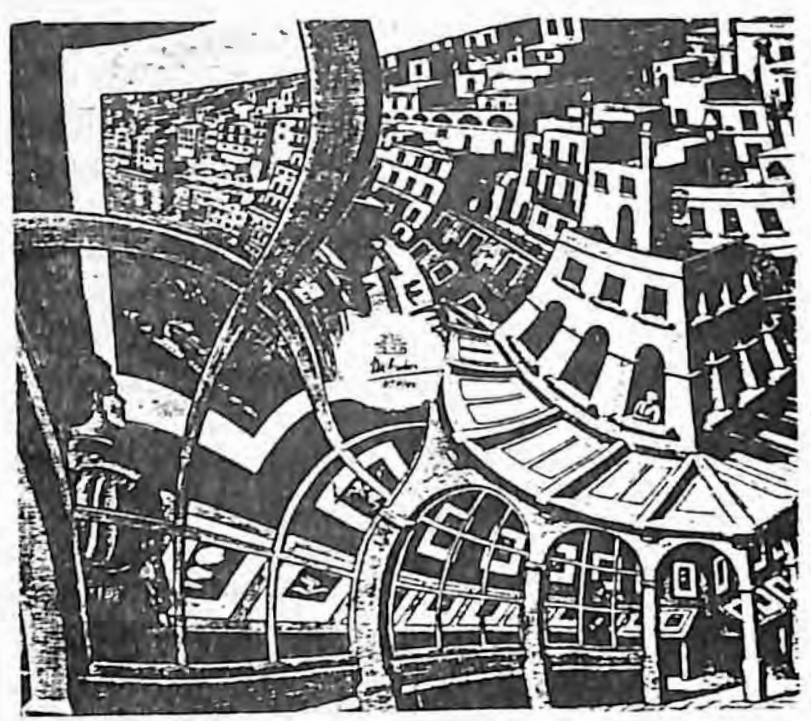

En "A vista perdida", el sujeto de la enunciación se sitúa y definne en el verso inicial: "No renunciaré jamás al lujo insolente al desenfreno suntuoso de pelos como fasces finisimas colgadas de cuerdas y de sables" y reaparece en el verso final: "No renunciaré jamás al lujo primordial de tus caídas vertiginosas oh locura de diamante". Entre el primero y el último verso $^{8}$ se interponen veinticuatro segmentos que desplazan al sujeto, desprendiéndose de él y originan una existenmcia autónoma. Este

hispanoamericana, México, Fondo de Cultura Económica 1985, 2a. ed., p.346.

8 Sólo la disposición espacial del poema y las mayúscula iniciales autorizan a que utilicemos la convención de "verso" para referimos a estos fragmentos, que son lo que en rigor constituyen el texto. 
desplazamiento produce la construcción de un espacio generador de significantes puntuando una realidad fluyente. Los sintagmas nominales iniciales producen un ritmo que va en progreso, hasta la aparición de "El estupor" (verso 10), que inicia un segundo movimiento, marcado por la serie de determinaciones nominales generadas asindéticamente a partir del patrón nominal /estupor/. Varía entonces el ritmo, que se acelera debido a la progresión nominal producida en el interior de cada fragmento:

El estupor

El estupor de cuentas de cristal

El estupor de vaho de cristal de ramas de coral de bronquios y de plumas

El estupor aubmarino y terso resbalando perlas de fuego impermeable a la rtisa como un plumaje de ánade

delante de los ojos... (p.53)

hasta alcanzar un vértice en que las imágenes construyen fragmentos extensísimos de hasta seis líneas ${ }^{9}$. Esta proliferación no constituye, desde el punto de vista del significado, un aumento de información, asi como tampoco admite progresión en la lectura, pero sf dibuja un movimiento de paulatino acercamiento del objeto /estupor/, cuya repetición transforma el significado denotado (Disminución o paralización de las funciones intelectuales, asombro, pasmo) hasta lograr connotarlo como objeto, como entidad separada del sujeto y, por lo tanto, dotado de una existencia independiente.

\footnotetext{
9 Se trats del único segmento en que no opera una fragmentación nominal fuerte; en él, la imagen de la mujer enseñando la imagen de la Virgen remite a paisajes (visiones) alucinados de BÖsch, y constituye uns figurativización de lo femenino característica del surrealismo: "mujeres desnudas sobre colchones de cáscsras de fruts", "mujer que duerme desnuda" (p.54).
}

La geminatio opera, pues, por iteratividad $^{10}$ y el ritmo se produce como resultado de la alternancia entre repetición y variante del patrón nominal. La anáfora fija el eje paradigmático, lo que produce un movimiento de atracción hacia este eje de la variación operada en el sintagmático, absorbiéndola, lo que además es reforzado por la ausencia de puntuación. De este modo tiende a neutralizarse la única variante: "Bocas de dientes de azúcar... y variables de saliova" inscripta en el paradigma. El movimiento de menor a mayor medida (versos 10 a 14), interrumpido en el verso 15 por la variante mencionada, que altera levemente la anáfora, es retomado inmediatamente de igual manera (versos 16 a 21), creándose un dibujo rítmico circular y envolvente alrededor de sintagma "el estupor", en ondas de expansión yconcentración -el vértigo y la fijeza ${ }^{11}$. . La cohesión lograda por el ritmo y la geminatio, de movimiento sostenido, se apacigua en los versos 22 y 23 , para detenerse finalmente con la reaparición de la voz del enunciador, en dos sintagmas nominales que actún a nivel metatextua explicitando la concepción surrealista de la realidad, -que hace de la secuencia regida por anáfora su poetización:

"El grandioso crepúsculo boreal de pensamiento esquizofrénico / La sublime interpretación delirante de la realidad" (p.54) constituyen la opción voluntaria de un sujeto, que se escinde de la visión

\footnotetext{
10 -Esta iterabilidad -iter directamente vendría de itara otro en sánscrito- y todo lo que sigue puede ser leído como la explotación de esta lógica que une la repetición a la alteridad. Esta iterabilidad estructura la huella de la escritura misma..." Cfr. Derrida, Jacques, "Signature evenement, contexte", en Marges de la philosophie Montreal, Les Editions de Minuit, 1971, p.375. (La traducción es mía).

11 Como observa Sucre, no se trata de una poesía que tienda a sustantivar las imágenes; antes bien, su efecto consiste en fijar las imágenes en el vértigo. Cfr. Sucre Guillermo op. cit., p.347.
} 
racional marginándose de la escena (desapareciendo como hablante poéticu para ejar paso a la mirada) para decir a la realidad, la que ahora se presenta como una yuxtaposición de imágenes. Más que una voz, lo que el texto construye es una mirada que fija las imágenes en la sucesion. No hay, pues, ruptura de lo real, como no la hay del lenguaje: la posibilidad de un lenguaje no sujeto a las categorías racionales son explícitamente señaladas en el poema. Lo que se impugna es a la razon que mediatiza y empobrece la realidad organizándola en categorfas; de este modo se intenta apresar el fluir de la realidad sin que medie la conciencia razonante.

El acceso a esa realidad más plena supone, entonces, un doble movimiento; ta marginación del sujeto y la objetivación del deseo (el estupor). Se postula asf la petición de un lenguaje otro a partir de un método: el "pensamiento prolijo" que fija al significante; es ese significante el que metonimicamente convoca a otros significantes, mostrando las posibilidades ilimitadas de la geminatio. La "estereotipia" (repetición involuntaria de una palabra) como posibilidad metódica de conocimiento de la realidad, parece atribuirse fundamentalmente al lenguaje de la locura ${ }^{12}$ : La palabra designando el objeto propuesto por su contario

$$
\begin{aligned}
& \text { La perdida de las facultades y la adquisición } \\
& \text { de la demencia } \\
& \text { El lenguaje afásico y sus perspectivas } \\
& \text { embriagadoras }
\end{aligned}
$$

12 Relata Westphalen: "Bajo la influencia de César Moro * intensificó mi interts por el arte, el psicoańlisis, el marxismo, la antropologia. Con él asistí a un curso de psiquiatría que dictaba en el hos[pital Larco Herrera el Dr. Honorio Delgado para los estudiantes de San Femando". Cfr. Weatphalen, E., op. cit., p.118. Esto ocurria hacia 1934, recién llegado Moro de Francia; cabe recondar que el poeta organizó exposiciones de pintura de los internados en el hospicio.
La logoclonia el tic la rabia el bostezo interminable

La estereotipia el pensamiento prolijo ... (p.53).

Más precisamente, es en la esquizofrenia donde se advierte la disociación y la disgregación del pensamiento: la pérdida de cohesión en las asociaciones, ocasionada por la Spaltung o escisión lleva a una "independencia cada vez mayor de objeto pensado"13, aspecto éste que fuera teorizado por André Breton en "Situación del objeto surrealista", de $1938^{14}$, y presente en los manifiestos de movimiento, bajo la forma de exaltación de los estados no racionales, momentos en que se borran los límites. entre la normalidad para acceder a otros estados onirismo, locura, videncia ${ }^{15}$. El título de

13 Cfr., en este sentido, los efectos de la Spelaung como trastomo de las asociaciones en el pensamiento, síntoma de la esquizofrenia, en relación con el deseo, en Laplanche, Jean y Jean-Bertrand Pontalis, Diccionario de Psicoanálisis, Barcelona, Labor, 1971, p. 125-130. Esto procesos mentales de la enfermedad seguramente cran conocidos por Cesiar Moro.

14 - La pintura confronta esta representación interior con la representación de las formas concretas del mundo real busca, hal como ocurre en la pintura de Picasso aprehender el objeto en su aspecto general, y, cuando to ha conseguido, intenta aquella tarea suprema que es la tarea poética por antonomasia: excluir (relativamente) e objeto exterior en cuanto tal, y considerar la naturaleza únicamente en su relación con el mundo interior de la conciencia." Cfr. Breton, Andre, "Situación surrealista de objeto", en Manifiestos del Surrealismo, Trad. Andre Bosch, Madrid, Guadarrama, 1980, p. 281.

15 Piénsese en la particular atracción que sobre Moro ejerció el relato de Leonora Carrington, Abajo, que recogió en "Las Moradas" en los números 5 Gulio de 1948) y 6 (octubre de 1948). En la "Nota" que precede a la traducción, Moro alude a "su facultad única de transtocar los materiales comunes en oro purísimo $y$ brillador, en cristales y cuarzos preciosos". Cfr. Moro Cesar, Versiones del Surrealismo, Julio Ortega ed. Barcelona, Tusquets, 1974, p. 81. Nótese la similitud de 
poema "A visæa perdida" anuncia esta operación de clausura de lo racional, este abandonarse de la mirada, como la voz poética en el objeto, para ingresar en la terrible, la insoportable belleza de un paisaje de locura "16. Es esta visión la que hace del sujeto un alienado, que opta orgullosamente por la condición de exilio. Los dos segmentos el inicial y el finalproponen, pues, la construcción de un sujeto solitario en busca de la belleza17.

"El fuego y la poesía" es el título del poema más extenso de $\mathrm{La}$ tortuga ecuestre; está compuesto por seis seccines numeradas con romanos. Las secciones tienen entre 14 y 24 versos, dispuestos de

imfigenes entre este fragmento y el verso final del poema "A virat perdido" (p. 54).

16 Julio Cortizar, un heredero del Surrealismo, eseribió en el prólogo a Ficmanario: "La gran paradoja es asomarse a la locura sin cstar loco, ser el mirón al borde del acuario dondo el pulpo hace y deshace soñoliento sus vagas nubes de tabaco y pesadilla. Cuando afloran de nuestro lado algunos, raros testimonios de esa realidad incansablemente contigila, lo que se alcanza a decir y entender es apenas una ráfaga lejana, la puerta que se entorna para dejar pasar un hilo de luz y acaso un dedo o una mireda... El poeta, que no acepta el lenguaje con su intención puramente racional, ve muchas cosas convergentes y colindantes en términos como razón y locura, e incluso prefiere eliminartos para aprehender directamente eso que es un loco o un cuerdo; como está resueltamente instalado en la zona axial, au visión permeable le muestra todo proyecto de hombre por venir como integración fecunda y saltarina de componentes que vienen de los primeros grados de la razón y la sinrazón, alli donde nace un territorio común, donde la lógica aristotelica no es soberana absoluta sino solamente constiucional." Cfr. Facio, Sara; D'Amico, Alicia; Cortazar, Julio, Humanario, Buenos Aires, La azotea, 1976, p. 12-15.

17 La opción por el exilio es enaltecida por Moro con imigenes austuarias y reales: "Hay que llevar sus vicios como un manto real, sin prisa. Como una acuarela que ignoramos y fingimos no advertir."; "Mi púrpura está manchada, igual que los tignes, los animales de pelaje o de plumes". Cit. por Sucre, Guillermo, op. cit., p. 351. la siguiente manera: I: 14 v.; II: 21 v.; III: 20 v.; IV: 24 v.; V: 21 v.; VI: 21 v. La cohesión y la progresión se presentan en los versos iniciales de cada sección:

I. "Amo el amor..."

II. "Amo el amor de ramaje denso"

III. "Amo la rabia de perderte"

IV. "El agua lenta el camino lento los accidentes lentos"

V. "Verte los días el agua lenta"

VI. "El agua lenta las variaciones mínimas lentas"

La estructura de los versos iniciales de cada sección es anafórica. Como en e poema "A vista perdida", se produce un autogenerarse del poema a partir de estos enunciados nucleares; estos . patrones sintácticos desencadenan la variación:

amo cl amor

amo el amor de (más determinantes)

$$
\begin{aligned}
& \text { el amor como (más términos de com } \\
& \text { paración) } \\
& \text { el amor (más preposición y complementos) }
\end{aligned}
$$

y su repetición origina la geminatio a nive sintáctico, cohesionándolo a nive semántico, lo que produce un efecto de amplificación emocional. La geminatio a inicio del verso propone, además, un ritmo anafórico de tipo letánico; a ello debe agregarse la duplicación a nivel fónico en el interior de la frase: /AMO el AMOr/. De modo que la geminatio a nive sintáctico y semántico se presenta como e procedimiento más constante en el texto.

La confrontación del sujeto textual es paralela e intrínseca a la constitución de objeto poético (el amor): la voz es e vehículo de un nombrar y paulatinamente es absorbida por el objeto, movimiento que se produce entre la primera y la segunda secciones. Así, en la primera, sobre un total de 14 versos se produce una triple ocurrencia ("Amo el amor..."), en tanto que en la segunda sección la ocurrencia se da sólo al principio, para ser 
suplantada luego por el sintagma "El amor" y sus variantes (aposición, complemento preposicional, comparación); hacia la mitad de esta sección la iteratividad se desplaza hacia la elisión, desde el verso "La pérdida total del habla..." para centrarse en la autogeneración del objeto, escindido del sujeto del enunciado inicial.

En la tercera sección ocurren modificaciones sustanciales: el primer verso "Amo la rabia de perderte"-, al mismo tiempo que se construye siguiendo el patrón inicial, sustituye al objeto /el amor/ por ha rabia/, aun cuando luego ambos términos no parezcan axcluirse semanticamente. Por otra parte, constituye una repetición del verso "La rabia dé

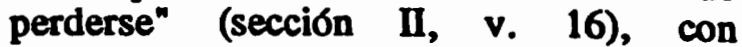
variación de pronombre -se/-te en posición enclitica y ambos en función refleja. Con ello se instaura un juego pronominal que por momentos tiende a la con-fusión y por momentos instala la oposición presencia/ausencia en el espacio poemático.

"La rabia de perderse" de la sección II instala la sensación de un abismarse de la voz poética en el torbellino del lenguaje, y lleva a "la pérdida total del habla del aliento / El reino de la sombra espesa" y construye la imagen pura del objeto "amor", por medio de la repetición; ésta lleva, por una parte, a un paulatino desprendimiento de ataduras conceptuales $y$, por otra, produce un ritmo hipnótico, de ritual, y permite aislar al sujeto del enunciado, objetivarlo, descubrirlo en el brillo de su cristalización. En ese proceso de aislamiento, el sujeto de la enunciación es absobido por el ritmo nominativo ${ }^{18}$; se

18 Dice Octavio Paz: "La empresa poetica no consiste unto en auprimir la personalidad como en abrirla y comvertirla en el punto de intersección de lo subjetivo y lo objetivo. El surrealismo intenta resolver la vieja oposición entre el yo y el mundo, to interior y lo exterior, creando objetos que son inleriores y exteriores a la vez." Cfr. Paz, presenta entonces con el atributo de la desnudez, preanunciando una segunda instancia, de revelación, que acaecerá en la tercera sección:

La pérdida total del habla del aliento

El reino de la sombra espesa

Con los ojos salientes y asesinos

La saliva larguísima

La rabia de perderse

El frenctico despertar en medio de la noche

Bajo la tempestad que nos desnuda

Y el rayo lejano transformando los árboles

En leños de cabellos que pronuncian tu nombre

Los días y las horas de desnudez eterna (p. 63)

Varios elementos confluyen hacia este momento de climax: el nombre, la noche, la desnudez, la temporalidad; todos ellos constituyen el campo semántico de la experiencia poética, concebida como una práctica que permite el acceso a una realidad más plena, acceso cuya vía se encuentra en la palabra como repetición y transformación ("Y el rayo lejano transformando los árboles / en leños de cabellos que pronuncian tu nombre").

La III sección se estructura en dos momentos diferenciados: el primero ocupa los primeros quince versos, el segundo los cinco finales. De este modo, en términos de macroestructura, los cincuenta primeros versos preparan el camino hacia una revelación que se produce en los últimos cinco versos de la sección III.

Dentro de esta sección se retoma e patrón rítmico-sintáctico de las anteriores; la iteratividad opera tanto en el eje paradigmático como en el sintagmático, lo que permite observar que en este extenso poema, Moro está trabajarido con escasos elementos, que combinados de una u otra manera, producen el efecto de un fluir nominativo. Además, la geminatio como

Octavio, "El Surrealismo", en Las peras del olmo Barcelona, Scix Barral, 1971, p. 144. 
figura que rige la construcción del discurso, continúa en esta sección en la que despunta una estructura opositiva inicial marcada por los pronombres. Como indicamos más arriba, esta sección es fundamental en la tematización y progresion; en primer lugar, mientras en las dos anteriores secciones el sujeto del enunciado es /el amor/, en ésta interesarán otros elementos en la constitución de un proceso que, siendo poético, es a la vez amoroso. Asf, pues, semánticamente se delimitan oposiciones como amado/amante, ausencia/presencia, ser posefdo por el tiempo/poseer el tiempo, dfa/noche.

En cuanto a la pareja amado/amante, es en este último término donde se concentra la actividad, onfrica, fundamentalmente, pero también polémica, en tanto establece la relación con los elementos adversos a la posesión: el tiempo, la vigilia, la ausencia. El amado, por su parte, aparece en el poema como ausencia o en fuga perpetua:

Amo la rabia de perderte

tu ausencia en el caballo de los dís

Tu sombra y la idea de tu sombra

Que se recorts sobre un campo de agua (p. 63)

Se trata, en rigor, más que de una escritura que rememora la ausencia del amado, de la construcción de una imagen que aparecerá real en la constitución del proceso poético-amoroso; por eso en él adquiere relevancia la mirada del amante que apresa la imagen del amado (una traza, un reflejo en la superficie del agua), la aisla del transcurso temporal y la fija en un instante que permanece; la suspensión del tiempo es también anulación de la muerte. Esta permutación de las valencias negativas en positivas ocurre en un tiempo y en un espacio precisos: la noche, el poema. Los versos finales enlazados por la anafora /y/ que marcan una temporalidad de otro orden, no fragmentada por la diferencia día/noche, proponen el salto a un estado diferente:

$Y$ al fin es mío el tiempo

$Y$ la noche me alcanza

$Y$ el sueño que me anula te devora

$Y$ puedo asimilarte como un fruto maduro

Como una piedra sobre uns isla que se hunde (p 63)

La noche, pues, como posibilidad de acceder a una experiencia amorosa que acaece en el espacio poemático, permite referir la escritura surrealista al romanticismo alemán, del que Novalis constituyera una lectura frecuente entre los poetas de este siglo: "Y la Noche fue / Seno fértil / De las revelaciones", dice en sus himnos" y Breton: "El espiritu avanza, atraído por estas imágenes que le arrebatan, que apenas le dejan el tiempo preciso para soplarse el fuego que arde en sus dedos. Vive en la más bella de todas las noches, en la noche cruzada por la luz del relámpago, la noche de los relámpagos. Tras esta noche, el día es la noche" 20 .

Ahora bien, no podemos dejar de referirnos en este punto a una concepción amorosa, de antigua raigambre en la cultura occidental, que, creemos, es la que se intertextualiza en la poesf́a de César Moro: se trata de la tradición que concibe al amor como un proceso de carácter eminentemente fantasmático y que, originada en un cuerpo de doctrinas filosóficas, médico-fisiológicas y místicoreligiosas, aparece por primera vez poetizada en la lírica provenzal trovadoresca del doscientos, más tarde en e neoplatonismo y retorna en el siglo XIX con Baudelaire, Nerval y De Quincey. Según este cuerpo de doctrinas la génesis del amor era explicada como un proceso

19 Novalis, Himnos a la noche, trad. Francisco Elvira Herníndez, Madrid, Visor, 1974, p. 37.

20 Breton, Andre, "Primer manifiesto", en op. cit., p. 59. 
fantasmático: no un cuerpo externo, sino la imagen interior esto es, el fantasma impreso a través de la mirada en los espiritus fantásticos- es el origen y el objeto del enamoramiento, y sólo la elaboración y la contemplación de esta imagen puede generar una auténtica pasión amorosa. La fantasía, la memoria y el sueño concurrían a dar existencia a una imagen cuya visión interior permanecia aún en ausencia del objeto sensible. Según Giogio Agamben, el descubrimiento medieval del amor, es el descubrimiento de la irrealidad del amor, de su carácter fantástico. Tanto la historia de Narciso, uno de los temas más frecuentes de la iconografia erotica medieval, como la de Pygmalion, aluden ejemplarmente al enamoramiento de la imagen. A diferencia de la modernidad, el medioevo no concibe en el mito de Narciso el ser un amor de si, sino el ser amor a una imagen (un "innamorarsi per ombra"). "La fuente del amor o el espejo de Narciso aluden ambos a la imaginación donde mora el fantasma. Narciso, enamorado de una imagen, es el paradigma ejemplar del fin d'amors, y ademas, con una polaridad propia de la psicología medieval, es el fol amour que quiebra el círculo fantasmático en la tentativa de apropiarse de una imagen como si fuera una criatura real". 21

21 Cfr. Agamben, Giorgio, "Eros allo specchio", en Stanze. La parola e II fantasma nella cultura oceldentale, Torino, Giulio Einaudi ed., 1977, p. 99-100. (La traducción es mí) En el capítulo V, "I fantasmi di Eros", Agamben anota que en su catudio de 1917 sobre Duelo y melancolia, Freud descubre que el mecanismo de la melancolfa se basa en el conferir de una fantaemática realidad a un objeto perdido, pero, en cuanto es duelo por un objeto inapropiable, estrategia abre un espacio a la existencia de lo irreal y delimita una escena en la que el yo interta una posesión que ninguna apropiación podría igualar y ninguns pérdida podría scechar." (p. 28). Freud subraya el eventual carácter fantasmático del proceso melancólico, observando que la rebelión contra la pérdida del objeto amonoso puede alcanzar tal grado que el ajeto 
arrebatada al transcurso temporal ("Y al fin es mío el tiempo / $Y$ la noche me alcanza / $Y$ el sueño que me anula te devora") por medio de una alquimia poética que hace de la escritura "un amado espacio de revelaciones", por decirlo con palabras de Alejandro Pizarnik.

La IV sección se centra en la visión del cuerpo amado, tematizando el encuentro amoroso. El cuerpo del otro se objetiva a partir de una mirada que amorosamente va recorriéndolo. Esa mirada prismática que en otros poemas de La tortuga ecuestre permite el acceso a una percepción más plena del objeto mediante imágenes que procuran la descomposición del orden impuesto por la razón, se presenta ahora no como vehículo de dispersión sino de concentración; las imágenes se reducen frente al predominio de menciones al cuerpo. Es pues, esta concentración la que hace del cuerpo amado la máxima imagen: la imagen del mundo.

El cuerpo del poema es imagen del cuerpo amado, como éste lo es del mundo, desplazamientos que ocurren en la geminación lingūística; pero el cuerpo del poema está en lugar del cuerpo amado, opera por lo tanto, como sustituto de lo que no está. En César Moro el erotismo asumirá la forma del exilio, y la mirada, su vehículo, expresa esa distancia.

En la $V$ sección se evidencia más claramente el proceso al que aludimos; toda la sección está regida por el verbo verte, su recurrencia fija la imagen del otro: "Verte los días el agua lenta /... Verte si cuento la horas..." La mirada y el nombre son intermitentes, ambos son inscripciones que, como señala Sucre, restituyen a la escritura su sentido etimológico. Como en el movimiento anterior, el nombre invade el mundo y lo transforma:

Tu nombre aparece intermitente

Sobre un inmenso ombligo de panadería

A veces ocupa el horizonte
A veces puebla el cielo en forma de minúsculas abejas

Siempre puedo leerlo en todas direcciones

Cuando se agranda o se complica de todas las palabras

que lo siguen

O cuando no es sino un enorme pedazo de lumbre

O el paso furtivo de las bestias del bosque

0 una araña que se descuelga lentamente sobre $m$ cabeza

O el alfabeto enfurecido (p. 65)

Es este sentido, si avanzamos en la lectura hasta el primer verso de la última sección: "El agua lenta las variaciones mínimas lentas" (construído como una variante de "El agua lenta el camino lento los accidentes lentos"), se advięrte que la sección $\mathrm{V}$ constituye una re-escritura y una clave de la VI. En cuanto a ésta, deciamos, el nombrar en imágenes a cuerpo está en lugar de la percepción inmediata de éste, como si se tratase de una escena vivida en el sueño ${ }^{24}$ : ahora, en la $\mathrm{V}$ sección, se revela el sentido (no e único, pero sí uno de los que juegan en e texto) del ver y del nombrar.

Ver -creemos- debe ser restitufdo a código surrealista y entendido como la capacidad de acceso a una realidad recortada por la vigilia, la razón o la costumbre. En su "Carta a los videntes" Breton habla dicho: "Lo que es sera, en virtud únicamente del lenguaje, y nada podrá impedirlo." 25 , relacionando e trabajo de las videntes con el de los poetas. Es, pues, esa capacidad enriquecedora del lenguaje a través de sus

\footnotetext{
24 Dice Moro en otro texto: "La lucidez amanga de la satumales, la de la primera libación, la del vigilante silencioso nocturno, la de los últimos papadeos de la conciencia antes de naufragar en el agua translúcida de sueño." Cit. por Coyne, Andre, "No on vano ancido César Moro...", en ECO, 243, Bogotó, Buchholz, ene 1982, p. 306.

25 Breton; Andne, "Carta a las videntes", en op. cil., p 254.
} 
imágenes la que revela al objeto, lo hace real al anular las falsas antinomias. El nombrar, en relación con el ver, atiende a la acentuación del significante en su materialidad, sin ligazones referenciales. Es el significante el que, en el acto de ser nombrado, en su repetición, genera otras asociaciones: "Tu nombre aparece intermitente... Siempre puedo leerlo en todas direcciones". Es, como anota Julio Ortega, la "reconversión de la escritura antes del discurso en la construcción inaugural de un espacio de liberaciones. "26

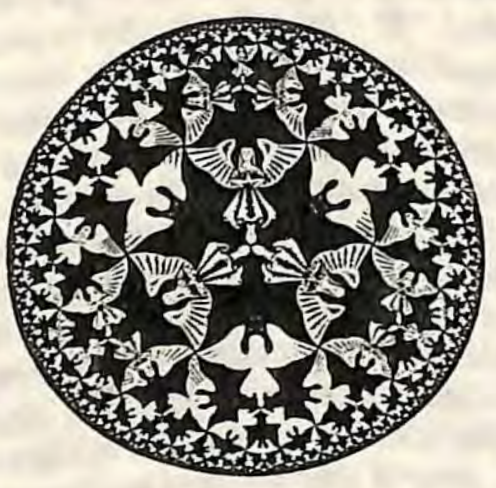

La sección final concluye este proceso poético remansando el ritmo, que ahora es producido por enunciados mucho más pas imágenes pierden la cohesión breves. por la recurrencia lexemática lograda y se perfila una nueva y última lentallentod que, si por una parte remite al espacialidaddeado" como espacio de "cuarto concentración, por otra alude, en máxima concón significativa al mar como espacio de lo indeterminado:

El agua cayendo lenta

Sobre el mundo

Junto a tu reino calcinante

Tras los muros el espacio

26 Ortega, Julio, "Ls escritura de la vanguardia", en Revista lberoanericana, Pitusburgh, Institito Internacional Revista lberoume Literatura toeroamericana, 106-107; 45 (1979) p. 195.
Y nada más el gran espacio navegable

El cuarto sube y baja

Las olas no hacen nada... (p. 65)

El mar, como la fauna marina, son presencias constantes en la poesía de Moro. Entre sus valencias, siempre positivas, se destaca la de ser un continuo, un espacio de posibilidades; el "cuarto", figurativizado en $/$ navio/, interseca con otro elemento, el fuego, caro a la imaginerfa surrealista. Agua y fuego coexisten en el inmenso ámbito de la noche, lugar de desaparición de los contrarios.

Los versos finales de esta sección subrayan el término del proceso con la llegada de la luz diurna:

El alba acecha para asestamos su gran golpe

Ciegos dormidos

Un úrbol ha crecido

En vano cierro las ventanas

Miro la luna

El viento no ha cesado de llamar a mi puerta

La vida oscura empieza (p. 65)

que reinstala el transcurrir temporal; e verso final $^{27}$ marca el retorno a un estado que esciende al sujeto de la imagen amada.

Asf, la construcción poética del cuerpo del otro, el nombrarlo, secede en el ámbito de la noche; su vasto campo semántico (fuego, luminosidad, poesfa) se opone a de día, como transcurrir del tiempo, dispersión y exilio de la imagen.

La pasión aísla al sujeto en un espacio poético habitado por la imagen fantasmática del amado, la que se construye en la escritura por medio de un nombrar que en su inacabable fluir asegura la existencia del objeto ${ }^{28}$. Por ello,

$27 \mathrm{Cfr}$. los versos finales de -Oh furor el alba se des prende de tus labios", p. 56

28 No existe en el texto de Moro un solo signo de puntuación, lo que hace de la escritura un fluir sin dique Este carácter inacahado del poema forma parte, como 
entendemos que si se produce una plenitud, esta no depende de la posesion de un objeto amoroso extrapoético y que serfa exaltado en el poema; antes bien, este goce reside en la construcción de un objeto de lenguaje. El motor que da origen a esta existencia -y que justifica al mismo tiempo la existencia de una voz y una mirada poética- es el deseo (la geminatio) de lo que no está. La intensidad del erotismo en la escritura de Moro se revela en el ser esta una escritura siempre demandante 29 . El lenguaje, pues, está en el centro de la ausencia y por ella es generado.

"El mundo ilustrado" es uno de los poemas en que se advierte con mayor claridad la aprehensión de una imagén (anclada anafóricamente) $y$ el paulatino aislamiento, en el espacio que ella crea, de la voz poética:

Igual que tu ventana que no existe

...

Con la misma igualdad con la continuidad preciosa que

me asegura idealmente tu existencia

...

$Y$ toda tu presencia sin cerrar los ojos

...

Y me encierro dentro de ti a mísolo

Dentro y lejos de ti... (p. 55)

El espacio del poema anula las coordenadas espaciales, al tiempo que el objeto (amado) convoca una apertura al mundo. En La tortuga ecuestre las imágenes del mundo de la naturaleza son constantes, aparecen más de setenta menciones a animales. Ese mundo revela su contigüidad con el cuerpo en la recurrencia del nombrarlo; asf, por ejemplo, en poemas como "Oh furor..." o

señala Roberto Paoli, del código surrealista. Cfr. Paoli, Roberto, op. cit., p. 199.

29 La carta es el género por excelencia de. la demanda y también escritura de la ausencia.
"El humo se disipa", en los que elementos del cuerpo como "tu frente" o "tu aliento" generan imágenes del mundo.

En un movimiento envolvente $e$ nombrar hace del sujeto nombrante un sujeto escriturario, función que otorga a la escritura un sentido de inscripción. En e texto inicial de Cartas (1939), el nombre "Antonio", reiterado anafóricamente veintiocho veces, conforma visualmente a poema en dos cuerpos" el de la izquierda construye una columna perfecta (un paradigma) y el de la derecha se forma con enunciados en los que predomina la copula verbal, lo que hace del poema un espacio ocupado en todas las direcciones por la nominación geminativa, incluso siguiendo el orden normal de la lectura el nombre "Antonio" ocupa el inicio y el final.

El nombrar tiene además otra función" la de detener un movimiento perpetuo de fuga de la imagen: "El humo vuelve y se acumula para crear representaciones/ tangibles de tu presencia sin retorno" (...) "Cierro los ojos y tu imagen y semejanza son el mundo"30 "Oh furor..." (p. 56); "Tan pronto llegas $y$ te fuiste..." "Vienes en la noche..." (p. 58); "Tener entre las manos largamente una sombra/ De cara a sol/ Tu recuerdo me persiga o me arrastre sin remedio/ Sin salida sin freno sin refugio sin habla sin aire" "Batalla al borde de una catarata" (p. 59);" Tratando de robarte a la realidad/ $\mathrm{Al}$ ensordecedor rumor de lo real/ Levanto una estatua de fango purísimo/ De barro de mi sangre" "La leve pisada del demonio nocturno" (p. 60)

30 Existe, en el nivel de la tematización un aspecto deificador en la construcción de la imagen amada, lo quo es visible en poemas como el inicial de las Cartas y on un sintagma como "y tu imagen y semejanza son el mundo" construido sobre la base del patrón lexicalizado "Dios hizo al mundo a su imagen y semejanza". Este aspecto tiene además relación con un cierto hieratismo que surge de la
menciones al cuerpo del otro. 


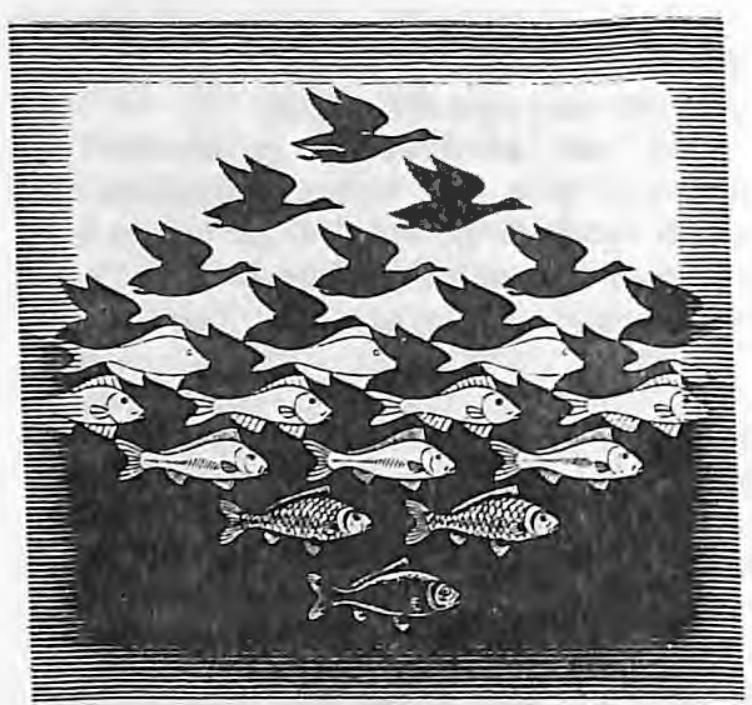

Estos ejemplos permiten observar que todos los elementos que aluden a la imagen del amado corresponden al campo de lo abstracto o connotan intangibilidad y revelan el carácter de constructo de la misma que, como deciamos se da en un espacio de exilio, habitado solamente por el sujeto y la imagen. En "Carta de amor", texto originalmente escrito en francés y traducido posteriormente por Westphalen, el recuerdo se reconstruye en la reiteración del verbo "pensar". El pensar como operación que extrapola al objeto para inscribirlo como tal en otro espacio, aparece como el único medio de confirmar la retención de una existencia en fuga ${ }^{31}$.

Pienso en las holutorias angustiosas que a menudo nos rodean

/al acercarse el alba

Pienso en tu cuerpo que hacía del lecho el cielo y las montañas

31 - 'Pensar en ti' no quiere decir otra cosa que esa metonimis. Puesta que en sí, ese pensamiento está vacío: no te pienso; simplemente, te hago aparecer (en la misma proporción en que olvido)." Cfr. Barthes, Roland, "Ls carta de amor", en Fragmentos de un discurso amoroso, México, Siglo XXI, 1982, p. 51.

\section{Pienso tu rostro \\ /supremas de la única realidad... \\ inmóvil brasa de donde parten la vía láctea...}

Intratable cuando te recuerdo la voz humana

Siempre el rumor vegetal de tus palabras

/me es.odioss

/me aísla en la noche total

donde brillas con negrura más negras

/que la noche..

No olvidaré nunca

Pero quien habla de olvido

en la prisión en que tu ausencia me deja

en la soledad en que este poema me abandona

en el destierro en que cada hora me encuentra...//

en el sitio y a la hora convenidos pero

/inhallables

en las llanuras fértiles del paroxismo

y del objetivo único

pongo toda mi destreza en

/deletrear

aquel nombre adorado

siguiendo sus transformaciones alucinantes... 32

El poema -como carta- es la escritura que se instaura en el espesor de la lejanra; ésta es, en definitiva, la condición de posibilidad de toda escritura amorosa. E exilio de la presencia y del amor, por naturaleza "intratable" cuando se lo está viviendo, es el que genera tanto a la imagen como al poema.

Saber que no se escribe para el otro, saber que esas cosas que

voy a escribir no me harán jamás amar por quien amo, saber

que la escritura no compensa nada, no sublima nada, que es

precisamente ahí donde no estás: tal es el comienzo de la

eseritura. 33

32 "Cartas de amor", en El libro de unos sonidos, selec de Reynaldo Jiménez, Buenos Aires, Ultimo Reino, 1988 p. 157-159.

33 Barthes, Roland, "Inexorable amor", en op. cit., p 122. 
El poema se construye en la obra de César Moro, como veĺamos, por medio del procedimiento de la geminatio: la variación a partir de un patrón que opera por repetición. En este sentido, y en consonancia con la filiación surrealista de Moro, el poema se revela como un constructo dotado de autonomía, en la medida en que, como indica Julio Ortega, el surrealismo propone la fractura del discurso naturalista representativo ${ }^{34}$. Asf, pues, el poema se propone como un espacio en que la existencia se ilumina en su autogenerarse. Exilio voluntario en la palabra, como morada de la Poesía, espacio en que se nombra al deseo y en que tiene lugar la maravilla. "Mientrás escribo -dice Moro- la noche dispensadora de maravillas enciende sus fuegos por el mundo; brillan las lámparas votivas de la Poesía como otras tantas estrellas dando su norma sideral, inútil quizá, al debate de los hombres... Fuera de ella -hilo de Ariadna-, la desesperación, el fragor estéril de las simulaciones, la ceguera que inmoviliza dentro del Laberinto..." 35

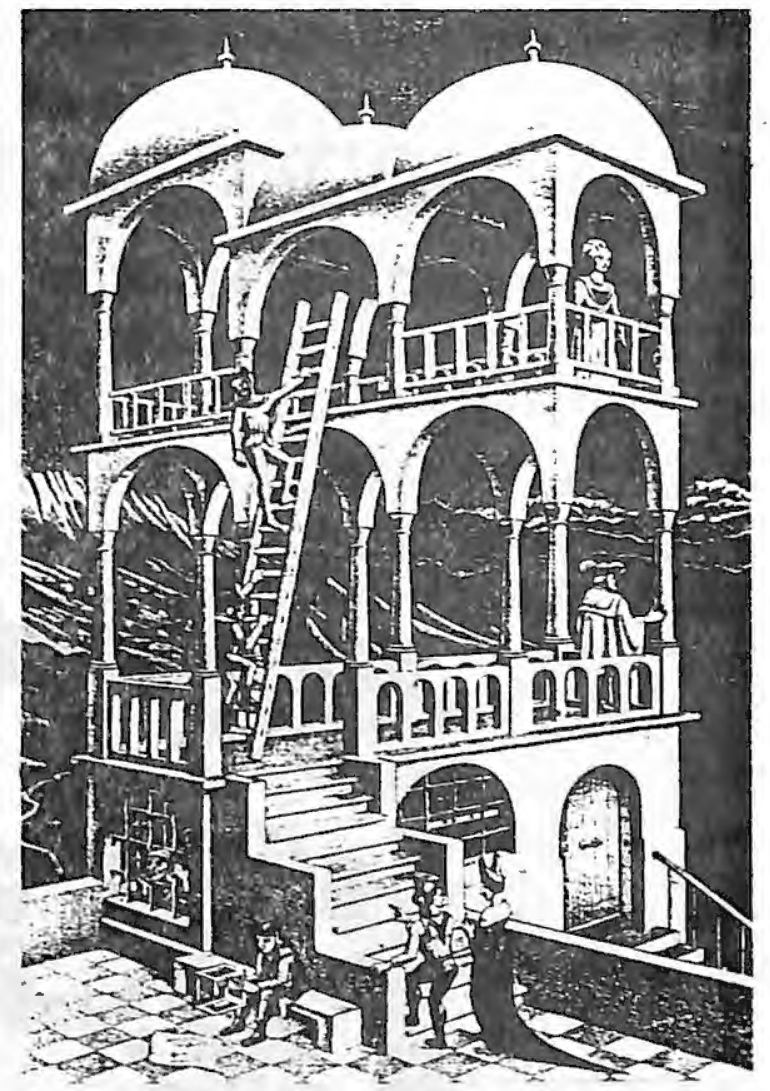

34 Cfr. Ortega, Julio, op. cit., p. 188-189.

35 Moro, César, "Carta a Xavier Villaurrutia", Las Moradas, 1949, cit. por Coyne, Andrर, op. cit., p. 304. 